\title{
The Three Cs of Administrative Office Management: Conceptions, Challenges, and Coping Mechanisms
}

\author{
Christopher D. C. Fancisco \\ City of Malolos Integrated School - Sto. Rosario, City of Malolos, Bulacan, Philippines \\ Email: christopher.francisco004@deped.gov.ph
}

Area of the Paper: Business Management.

Type of the Paper: Conceptual Research.

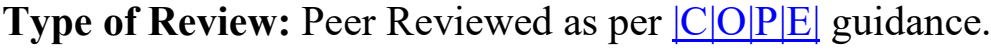

Indexed In: OpenAIRE.

DOI: http://doi.org/10.5281/zenodo.4113952

Google Scholar Citation: IJCSBE.

How to Cite this Paper:

Christopher D.C. Francisco (2020). The Three Cs of Administrative Office Management: Conceptions, Challenges, and Coping Mechanisms. International Journal of Case Studies in Business, IT, and Education (IJCSBE), 4(2), 169-175. DOI: http://doi.org/.zenodo.4113952

International Journal of Case Studies in Business, IT and Education (IJCSBE)

A Refereed International Journal of Srinivas University, India.

(C) With Authors.

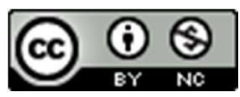

This work is licensed under a Creative Commons Attribution Non-Commercial 4.0 International License subject to proper citation to the publication source of the work.

Disclaimer: The scholarly papers as reviewed and published by the Srinivas Publications (S.P.), India are the views and opinions of their respective authors and are not the views or opinions of the S.P. The S.P. disclaims of any harm or loss caused due to the published content to any party. 


\title{
The Three Cs of Administrative Office Management: Conceptions, Challenges, and Coping Mechanisms
}

\author{
Christopher D.C. Fancisco \\ City of Malolos Integrated School - Sto. Rosario, City of Malolos, Bulacan, Philippines \\ Email: christopher.francisco004@deped.gov.ph
}

\begin{abstract}
The main aim of the study was to investigate different conceptions, challenges, and coping mechanisms with regards to administrative office management. To achieve this aim, the researcher selected three administrative officers within the Schools Division of City of Malolos, Bulacan during the school year 2019-2020. The study utilized a qualitative research design which aimed to describe the lived experiences of individuals in a certain phenomenon or human condition. Using transcriptions, codes, and triangulations of the data gathered, themes were extracted in the data analysis. Findings revealed that: (1) AOM was conceived as management of various documents for smooth transactions between teachers and school administrators, (2) AOM challenges were noted as encountering naughty teachers, unreturned office supplies, noisy location of the office facility and the office which is sometimes turned out to be a storage room, and (3) As AOM coping mechanisms, the respondents keep their strict mood and maintain a happy atmosphere to obtain a less stressed and a peaceful workplace. Conclusions were drawn and recommendations were offered.
\end{abstract}

Keywords: Administrative Office Management, Conceptions, Challenges, and Coping Mechanisms.

\section{INTRODUCTION :}

Administrative office management play a pivotal role in every educational setting. Administrative officers are the ones who are assigned in jobs related to management operations, procurements, teachers and student records, finances and so on. But lots of issues have been found as cited by different personnel in terms of handling situations that are really risk-taking and difficult due to heavy workloads - which in effect entails their job satisfactions despite their best practices. The main aim of this paper was to investigate different conceptions, challenges, and coping mechanisms with regards to administrative office management in the Schools Division of City of Malolos during the academic year 2019-2020.

\section{RELATED WORKS :}

A study found out that hygiene and motivation factors are related to one another. Providing employees contingent rewards and recognition make them feel that they are important [1]. But an issue on providing them learning and professional growth were identified [2] This means to say that since they have no professional development and engagement opportunities, they lack visibility, disengage and ultimately may separate from their institutions.

It was also stated in a study that teaching and non-teaching personnel did not see much prospects in the future in the current organization where salary is the number one reason why employees in the private organization intend to transfer of employment. Thus, both private and public institutions are challenged to find a way to solve employee attrition in order to sustain the operation of the company [3].

School leadership, therefore, was tasked to help faculty developed their potentials so that they could contribute to the attainment of the objectives of the university [4]. If leaders would fail to inspire its people, it could result to low performance of the institution. Among the seven dimensions of Spiritual Leadership altruistic love and productivity were found to be significantly different between the teaching and the nonteaching personnel. It was recommended that leaders should continue to tap its employees and communicate clearly the directions of the institution. Furthermore, the fair and just working environment should be strengthened so that, it would be felt by all employees. Enough support should be given to all employees 
based on their needs to increase their productivity. Thus, a leader should promote healthy working environment in order to increase job satisfaction among employees. Thus, leadership can change employees' perspective as well as their morale towards work [5].

Motivation and commitment play an important factor in an organization [6]. In fact, the effectiveness of an institution is measured when it could be able to maintain employees link to its ability in managing the staff as well as recognizing the individual's job. It was found out that non-teaching personnel were highly motivated on intrinsic motivation and moderately motivated on extrinsic motivation. This means to say that non-teaching personnel were moderately committed towards their career, while they were highly committed towards the organization. Hence the motivation of the non-teaching personnel played a significant role in their level of commitment towards their career and to the organization. [7].

An international study conducted regarding the motivation factors for non-teaching staff of a public university. It was found out that performance appraisal practices have no significant differences among government and private universities. They concluded there was a significant impact of overall HRM practices on job satisfaction among teaching and non-teaching staff of both the government and private institutions [9] [10] [11].

Records management seeks to efficiently and systematically control the lifecycle of records that are routinely generated as a result of activities and transactions [12]. In this sense, learning needs assessment of the non-teaching personnel has a fundamental role in education and training since they are part and parcel of every organization. Thus, they must also be given much attention too beside the teachers. [13]. There is no doubt that school managers dream to achieve excellent performance of their schools, but it entails giving much attention on management of all employees (including teaching and non-teaching staff) because their abilities, motivation and performance can indeed determine the desired results of schools [14] [15] [16]. Lastly, a highly reinforced by technology leadership which was defined by vision, planning and management and evaluation and research, can result to strengthened management practices of high caliber [17].

With these underlying issues, problems, ideas and concepts, the researcher purported to evaluate different conceptions, challenges, and coping mechanisms with regards to administrative office management.

\section{STATEMENT OF THE PROBLEM :}

The study aimed at investigating the different conceptions, challenges, and coping mechanisms as regards to administrative office management. Specifically, the researcher sought to give light the following questions:

1. What is the respondents' perceptions about administrative office management?

2. What are the challenges encountered by the respondents in administrative office management?

3. How do respondents cope up with the challenges encountered in administrative office management?

\section{METHODOLOGY :}

\subsection{Design}

The phenomenological method was used in this study wherein qualitative data were utilized in form of narrations. A focus group discussion was conducted with the participants to explore their insights about their lived experiences as they selflessly fulfill their duty as administrative officers assigned in school. The method was phenomenological since it aimed to describe their perceptions and lived experiences. According to Center for Innovation in Research and Teaching of Grand Canyon University, the purpose of this design is to describe human experiences, reactions, feeling, perspectives, ideas, thought, and responses to a particular stimulus, called 'bracketing'. This design allows the researcher to dig into the relevant perceptions, substantial perspectives, understandings, and unexpressed feelings of those people who have actually experienced or lived the phenomenon or situation of interest, or the so-called, "lived-experiences." Specifically, the researcher mainly focused on the perceptions, challenges, and coping mechanisms of the respondents with regards to administrative office management. This qualitative study obtained phenomenological inquiry through casual and informal conversation to obtain the lived experiences of the administrative officers which were conducted last October 17, 2019 in the Division of City of Malolos, Bulacan. 


\subsection{Respondents}

The respondents of the study comprised three (3) administrative officers of the Schools Division Office of City of Malolos assigned in schools. As observed, the researchers did not go with the detailed presentations of the respondents so as to hide their identity for confidentiality purposes.

\subsection{Instrument}

A semi-structured interview was used in this study and it allowed the researcher to have flexibility in interviewing the participants. The survey questions were validated by the pool experts in the field to ensure that the needed data would be elicited. Likewise, the researcher wished to accurately capture the data and as a result all the interviews were audio-recorded. After the interviews were transcribed and analyzed, the data were treated and kept carefully for confidentiality purposes.

\subsection{Data Analysis}

The code and theme procedures were used in analysing and interpreting the narratives of the respondents. The researcher abstracts the themes from the code. After which, the data processed were triangulated and checked by the respondents.

\subsection{Data Gathering}

For the smooth flow of the data collection, the following procedures were carefully followed by the researchers: (1) The researchers briefed the participants about the study and informed them that participation was voluntary. They were given a choice if they wanted to be part of the study or not. (2) The tape-recording consent form was then presented to them, which asked for their permission for the interviews to be recorded. (3) The researcher wished to be transparent, and as a result, the participants were given the interview guideline. The interview guideline was given ahead of time before the day of interview to help them prepare themselves. The interview guideline aided in providing information-rich answers, as the researcher had time to prepare for the interviews. (4) The participants were interviewed individually in a private and quiet room. Semi-structured, one-to-one interviews were used as in-depth information of the understanding was needed, and also to allow the researchers some degree. (5) The tape recorder was used during each interview. Making use of an audio recorder allowed the researcher to record fully and accurately what was being said rather than taking notes during the interviews of flexibility in asking questions.

\section{RESULTS :}

The results were presented based from sequence and order of the questions raised:

Problem 1: What is the respondents' perception about administrative office management?

Based from the respondents, office management is to make sure and keep smooth transactions between teachers and administrations. This also manage the incoming and outgoing transactions especially the documents from the Division Office to the school or from the school to Division Office. The office manages them correctly. Nevertheless, our main function is not directly for the students, but for the teachers. Hence, we are the mediator between the school and the school's division in terms of transactions.

AOM is tasked to manage specific documents such as Good moral, Form 6, Certificate of Enrolment, Certificate of Employment, Liquidations, Enrollment Processes, Transaction Slips, Service Records, Request Forms, Endorsement Letters, Memoranda, and division advisories.

AOM divide works since we are not just three here despite the fact that we are still insufficient to serve more than 5 thousand students and personnel. One for the Elementary Department, one for the High School Department, and one for Senior High School and on Special Program for Special Education.

Technically, we have to sort out the documents (per department) by week, by month, and by year so that when someone comes, we know where to look after their documents. For the soft copies, we have to categories the documents into three: Liquidations of MOOE, Feeding Program, and Accounting Records. For the hard copies, I use fillers, dividers, envelopes, drawers, folders, and always make sure that files/documents should be in a proper place with labels.

Problem 2: What challenges do the respondents encounter in their workplace?

One of the challenges I encounter is that every time a teacher fails to submit his/her Daily Time Record/DTR with the attached Form 6 . We have to submit these documents until the very last days of the month, but there are still teachers who are submitting their DTR up to first week of the following month. 
Compared with our transactions with the parents, we don't have any problems with them as we have a very smooth transaction with them. Once they requested for documents (COE for example), immediately they will receive it that day.

Since teachers usually encounter lack of bond papers and all, they come here to ask for bond papers and other supplies. Sometimes, they borrow things here, but they don't return it. The MOOE is usually allotted to electric bills. But we find it hard to say No to them since all office supplies are for office only and we need to account all the things that we have here since we are all accountable for it.

Since our office is located beside the Aldaba Hall where all the school and district events happen, and behind the covered court, we cannot focus on what we are doing because of very distractive noise. An ideal office environment entails peaceful and silent atmosphere.

The offices are for document transactions. But, in our case, the district supervisor always put all the supplies (which is intended for the whole district) in our office. One of our dilemmas is that, what if these supplies get lost? We are not even informed about it. Since these supplies were placed inside our office, it is our accountability.

Problem 3: How do they cope up with those challenges encountered?

As administrative officers, sometime we cannot help ourselves but to show strictness towards teachers. It is in order for them to realize that a proper behavior and attitude must manifested from them whoever they talk with. They also need to be punctual in submitting reports, and other school forms especially the DTR. Despite our strict mood, we also keep a happy atmosphere in our office so that we don't feel stress and this is actually part of our self-management. At the end of the day, "Trabaho lang, walang personalan." "Dinadaan na lang sa biro." (We commit to our job and we used to make fun at the end of the day despite stressed working environment)

The increase in the salary of teachers should also be the increase in the salary of the Non-Teaching staff like us. For instance, during the Teachers' Day, we fail to receive as the same as what the teachers received during the celebration. The benefits of teachers are totally far beyond the benefits and incentives that we get. Another example, for Teachers, they are only required to stay at school for 6 hours but we need to stay for 8 hours. We don't have chalk allowances and anniversary bonus. The salary grade for Admin Aide is only SG 6, for Admin Assistant is only salary grade 8, and Administrative Officer with SG 11. We also need to get what we deserve if these salary grade entries will be granted. "Mahirap din naman trabaho namin." (Our work is challenging too.)

\section{DISCUSSION :}

Non-teaching personnel are considered the support group in attaining the mission and vision of the school in providing quality education for its students. The non-teaching personnel are indeed partners of teachers and schools administrators in administrative office management. Without them, it will be more difficult for the administrators to operate the school system since there are nobody who will help him or her in paperwork and in records management. That is why, determining their organizational job satisfaction needs to be given much attention because they are important component of success in maintaining excellence in providing quality services [18]. Although some studies would tell that administrative officers or the nonteaching personnel are satisfied in the services being provided to them by some institutions, yet they are still lacking in terms of contingent rewards and fringe benefits. Thus, every social organization such as the school is an embodiment of human beings who interact with one another in one way or the other and having specified roles to perform in line with their assigned duties but dependent in terms of intrinsic and extrinsic values [19]. Hence, an effective personnel management is needed in order to avert conflicts and equally manage conflicts when they inevitably occur. This means that the success of any organization is not only determined by the quality of personnel available, but how well these human resources are harnessed and coordinated towards realizing the goal of the organization. Hence, a greater competence on the part of the management in handling staff could really enhance school success.

\section{CONCLUSIONS:}

The main function of the office management was to have a smooth transaction between teachers and school administrators. Documents such as Good moral, School Form 6, Certificate of Enrolment, Certificate of Employment, Liquidations, Enrollment Processes, Transaction Slips, Service Records, Request Forms, Endorsement Letters, Memoranda, and division advisories are the specific paper works of the administrative officers. Furthermore, administrative officers are having divisions of work and proper 
sorting out of documents. Office challenges were found in naughty teachers, office supplies, location of office itself, and office turned out to be a storage room. They cope up with the given situations by keeping a strict mood for naughty teachers and maintaining a happy environment for less stress environment at the same time. Lastly, it was also noted that they are in favor of hiring new officers but the increase in the salary of teachers should also be the increase in the salary of the Non-Teaching staff like them.

\section{RECOMMENDATIONS :}

It was highly recommended that administrative office managers may be included in the Learning Action Cell (LAC) sessions to clarify things about the roles and responsibilities of the teachers in terms of submissions of documents, and to give attention about the teachers' attitude towards office management. Additional administrative office managers may be given assignments to schools with a ratio of two (2) officers is to Fifty (50) teachers. It appears exigent that a more competitive salary grades and benefits may be given attention by the Department of Education through the Civil Service Commission for the administrative office managers. From the salary grade 6 of administrative aide to salary grade 8 , from salary grade 8 of administrative assistant to salary grade 11, and from salary grade 11 of administrative officer to salary grade 13 .

\section{REFERENCES :}

[1] Javier, E. R., and Deligero, J. C. L. (2014). Job satisfaction of the teaching and non-teaching staff of the Lyceum of the Philippines University - Batangas. International Journal of Information, Business and Management, 6 (4).

\section{https://docuri.com/download/ibm 59c1cf74f581710b2863dc78 pdf\#page=6}

[2] Casis-Woidyla, R. (2020). Getting to the heart of professional development and employee engagement among non-teaching personnel in higher education: An appreciative inquiry into the influential role of a staff development center. Electronic Electronic Theses, Projects, and Dissertations. https://scholarworks.lib.csusb.edu/cgi/viewcontent.cgi?article=2233\&context=etd

[3] Ventayen, L. M., Ventayen, T. J. M. (2018). Proposed Action Plan to Increase the Work Contentment of the Teaching and Non-Teaching Personnel in Private Institutions. Asian Journal of Business and Technology Studies, 1 (2).

https://asianjournal.org/online/index.php/ajbts/article/view/125

[4] Delfino, A. P. (2019). Spiritual leadership and job satisfaction of teaching and non-teaching personnel of Partido State University People. International Journal of Social Sciences. 5 (2). https://doi.org/10.20319/pijss.2019.52.123140

[5] Francisco, C. D. C. (2019). School principals' transformational leadership styles and their effects on teachers' self-efficacy. International Journal of Advanced Research, 7 (10), 622-635. https://doi.org/10.21474/IJAR01/9875.

[6] Namoc, F. B., TIROL, J. A. B. (2016). Motivation and Commitment of the Non-Teaching Personnel of the Department of Education, Division of Bohol, Philippines. Multidisciplinary Research Journal, 4. https://doi.org/10.15631/ub.mrj.v4i1.79

[7] Asio, J. M. R., \& Jimenez, E. C. (2020). Professional development, organizational climate, supervisory rapport and overall satisfaction of employees: An attitudinal study. International Journal of Scientific Research in Multidisciplinary Studies, 6 (4), 34-40. https://doi.org/10.6084/m9.figshare.12698195.v2.

[8] Chowdhury, M. S., Alam, Z., Ahmed, S. (2014). Understanding employee motivation: The case of nonteaching staff of a public university. British Journal of Marketing Studies, 2 (6), 17-24. http://www.eajournals.org/wp-content/uploads/Understanding-Employee-Motivation-The-case-ofnon-teaching-staff-of-a-public-university.pdf

[9] Javed, S., Javed, R., Ahmed, N., Anjum, D. (2019). Human resource management practices and its impact on job satisfaction among employees in higher education sector. International Journal of Marketing and Human Resource Management (IJMHRM), 10 (2), 1-12. https://doi.org/10.34218/IJMHRM.10.2.2019.001 
[10] Asio. J. M. R., Riego de Dios, E. E., \& Lapuz, A.M.E. (2019). Professional skills and work ethics of selected faculty in a local college. PAFTE Research Journal, 9 (1), 164-180. http://doi.org/10.5281/zenodo.3980627.

[11] Asio, J.M.R. (2020). Effect of performance review and faculty development to organizational climate. International Journal of Management, Technology and Social Sciences, 5(2), 1-10. http://doi.org/10.5281/zendo.3976934.

[12] Adu, F. (2014). Assessment of records management practices among the administrative staff of University of Education, Winneba - Kumasi (UEW-K) and Mampong (UEW-M) Campuses. Theses / Dissertations College of Arts and Social Sciences (2014). http://ir.knust.edu.gh/bitstream/123456789/7540/1/Adu\%20Freda.pdf

[13] Lacsamana, R. M., Portugal, L., Delos Reyes, E. F. (2018). Learning Needs Assessment of NonTeaching Personnel as Input to Human Resource Development Plan. Asia Pacific Journal of Education, Arts and Sciences, 5(3). https://research.lpubatangas.edu.ph/wpcontent/uploads/2019/01/APJEAS-2018.5.3.04.pdf

[14] Francisco, C. D. C., \& Celon, L. C. (2020). Teachers' instructional practices and its effects on students' academic performance. International Journal of Scientific Research in Multidisciplinary Studies, 6(7), 64-71. http://dx.doi.org/10.21474/IJAR01/987.

[15] Asio, J. M. R., \& Riego de Dios, E. E. (2018). $21^{\text {st }}$-century attributes and skills of a teacher in the perspective of college students. Zenodo. http://doi.org/10.5281/zenodo.3961838.

[16] Asio, J. M. R., \& Riego de Dios, E. E. (2019). The college students' perspective on what makes an educator well-qualified. Journal of Pedagogical Research, 3 (3), 126-138. https://doi.org/10.33902/jpr.v3i3.124.

[17] Bongcayat, J. T., Guhao, Jr., E. S. (2020). Structural Equation Model on Work Engagement of NonTeaching Personnel in Public Secondary Schools. Review of Integrative Business and Economics Research, 9(2). http://buscompress.com/uploads/3/4/9/8/34980536/riber_9-s2_41_h19-059_259316.pdf

[18] Mendoza, R. O., Laguador, J. M., Buenviaje, M. G. (2014). Organizational satisfaction and work engagement among non-teaching personnel of an Asian University. Asian Journal of Management Sciences and Economics, 1(1). http://research.lpubatangas.edu.ph/wp-content/uploads/ 2014/12/IJMSE

[19] Owojori, A. A, Asaolu, T. O., (2010). Critical Evaluation of Personnel Management Problems in the Nigerian School System. International Journal of Educational Sciences, 2(1). https://doi.org/10.1080/09751122.2010.11889995 